\title{
RESEARCH
}

\section{IS POSTHERPETIC NEURALGIA AN INEVITABLE END IN ELDERLY CASES WITH HERPES ZOSTER? AN EVALUATION OF AGE-RELATED RISK FACTORS IN THE DEVELOPMENT OF POSTHERPETIC NEURALGIA}

Turkish Journal of Geriatrics

DOI: 10.31086/tjgeri.2021.198

2021; 24(1): $41-49$

- Damla YÜRÜK ${ }^{1}$

- Ayçin YILDIZ TABAKOĞLU2

CORRESPONDANCE

\section{${ }^{1}$ Damla YÜRÜK}

Health Sciences University Diskapi Yildirm Beyazit Research\&Training Hospital , Pain Clinic, Ankara, Turkey

\section{Phone: +905319932378}

e-mail: damlayuruk@hotmail.com

Received: Oct 23, 2020

Accepted: Feb 26, 2021

\section{Abstract}

Introduction: The aim of this study is to evaluate the risk factors in the development of postherpetic neuralgia (PHN) in cases with herpes zoster $(\mathrm{HZ})$ over 65 and under 65 years of age.

Methods: 90 cases with a diagnosis of $\mathrm{HZ}$ were divided into 2 groups as over 65 and under 65 years of age. 3 months after the onset of the rash, those with VAS score $>3$ were considered as cases who developed PHN. The demographic and clinical data of the cases were compared statistically.

Results: In $90 \mathrm{HZ}$ cases; the number of $\mathrm{HZ}$ cases over the age of 65 was 38 $(42,2 \%)$, and the number of $\mathrm{HZ}$ cases under the age of 65 was $52(57,7 \%)$. PHN developed in $53(58.8 \%)$ of $90 \mathrm{HZ}$ cases. While the initial VAS score $(p<0.001)$ $(p<0.001)$ and the presence of chronic disease $(p=0,05)(p<0.001)$ were found significant in the development of $\mathrm{PHN}$ in both $\mathrm{HZ}$ cases above and under 65 years of age, antiviral intake in the first 72 hours $(p>0.05)(p>0,05)$ were not found significant. Also in the $\mathrm{HZ}$ cases over 65 years of age, the affected dermatome $(p<0.05)$ and in the $\mathrm{HZ}$ cases under 65 years of age, gender $(p=0,05)$ was found significant in the development of PHN.

Conclusion: Special protection, follow-up and treatment is needed to prevent the development of PHN in $\mathrm{HZ}$ cases over 65 years of age, especially those with sacral and trigeminal dermatomes and presence of chronic disease.

Keywords: Herpes Zoster; Neuralgia, Postherpetic; Risk Factors; Aged

${ }^{1}$ Health Sciences University Diskapi Yıldırım Beyazit Research\&Training Hospital , Pain Clinic, Ankara, Turkey

2 Health Sciences University Yüksek Ihtisas Research\&Training Hospital , Neurology Clinic, Bursa, Turkey 


\section{INTRODUCTION}

Primary infection with varicella-zoster virus (VZV) is clinically manifested as chickenpox in childhood or early adolescence. After infection, VZV settles in the dorsal root and cranial ganglia. (1) Herpes zoster $(H Z)$ often emerges clinically several decades after the initial infection as a result of reactivation of VZV and spreads to the related cutaneous dermatome of the affected ganglion segment. It is characterized by a painful vesicular rash. (2) According to previous studies, the lifetime risk of developing $\mathrm{HZ}$ rate is $9-34 \%$. (3) The most common complication of $\mathrm{HZ}$ is postherpetic neuralgia (PHN), which is continued symptoms beyond the healing of the rash. (4) The pain is unilateral and dermatomal, of moderate to severe intensity, and is described as a constant burning or stabbing sensation. Some individuals also experience allodynia. (5) Treatment can be difficult because of its resistance to analgesic drugs, and it can persist for months or even years. (6)

Most of the time, serological or virological tests are not used for the diagnosis of $\mathrm{HZ}$. The diagnosis is predominantly based on the signs and symptoms. Viral culture and the direct immunofluorescence assay and, polymerase-chain-reaction techniques are useful for detecting varicella-zoster virus DNA in fluid and tissues. (7)

For the consistency and reliability of studies investigating risk factors in the development of $\mathrm{PHN}$, time and pain intensity parameters should be clearly stated in the definition of PHN. Because the results of studies may be influenced by the definition. Persistent, refractive pain in the affected area at least three months after the onset of the rash is defined as PHN. In the definition of PHN, persistent pain includes the characteristics of being stubborn and continuous without interruption. (8)

There is a well-known lack of adequate randomized controlled trials on age differences in pain. In studies on pain prevalence, the age factor is generally ignored. The reason for this false thought is the idea that pain is a natural consequence of old age. (9)

In general, other risk factors have been compared in the studies to determine whether PHN developed. However, the geriatric $\mathrm{HZ}$ cases has not been studied within itself. The aim of this study is to evaluate the risk factors in the development of PHN in cases with $\mathrm{HZ}$ aged over 65 and under 65 years of age. Determining the risk factors for PHN may provide early advanced treatments before complications develop and also enable the regulation of vaccination policies.

\section{MATERIALS AND METHODS}

This retrospective randomized study was conducted at the Health Sciences University Bursa Yüksek Iihtisas Training and Research Hospital. The study was approved by the Health Sciences University Bursa Yüksek Ihtisas Training and Research Hospital Ethics Committee with protocol number 2011-KAEK-25 2020/09-07. Consent forms were obtained from all patients to be included in the study.

The diagnosis of $\mathrm{HZ}$ was made by the specialists of algology and neurology according to the clinical features and examination of cases. Cases with dermatomal rash which was typical unilateral (i.e. not crossed the midline), manifesting as a maculopapular rash on an erythematous base, than it turned into a vesicular-pustular appearance within 7-10 days and skin sensitivity by palpation were diagnosed with $\mathrm{HZ}$. In some $\mathrm{HZ}$ cases, the prodromal phase is not followed by the development of rash; this is termedzoster sine herpete. (10) These patients were not included in this study.

The inclusion criteria for the study were : (1) HZ diagnosis confirmed by a physician; (2) applicants to the hospital within one week from the onset of the rash. The exclusion criteria for the study were : (1) Unable to describe pain symptoms due to dementia, aphasia, or mental retardation; (2) zoster sine 
herpete; (3) Lost to follow-up.

A total of 99 patients diagnosed with $\mathrm{HZ}$ were enrolled in the study. Data on age, gender, presence of chronic disease (malignancy, diabetes, hypertension, chronic lung, kidney, and liver disease), initial visual analog scale (VAS) score after the onset of the $\mathrm{HZ}$ rash, affected dermatome, and antiviral intake within the first 72 hours were recorded. The severity of initial pain was evaluated using a 10-point VAS from 0 (no pain) to 10 (worst pain you can imagine).

After the onset of the $\mathrm{HZ}$ rash, pregabalin (150 $\mathrm{mg} /$ day and increased by $150 \mathrm{mg} /$ day up to 600 $\mathrm{mg} /$ day) treatment was prescribed for patients with VAS scores $>3$, while those with VAS scores $\leq$ 3 were not treated. Apart from the pain treatment recommended by the algology clinic, the patients were not allowed to take any other analgesics except pregabalin. Three months after the onset of the rash, pain severity in the affected area was assessed with the VAS score and by asking patients whether it differed from the pain experienced in the area at the onset of $\mathrm{HZ}$ rash. (Table 1)

The cases were divided into 2 groups as over 65 and under 65 years of age. 3 months after the onset of the rash those with VAS score $>3$ were considered as cases who developed PHN and VAS score $\leq$ 3 were considered as cases who did not developed $\mathrm{PHN}$. The demographic and clinical data (age, gender, presence of chronic disease, initial VAS score after the onset of the $\mathrm{HZ}$ rash, affected dermatome, and antiviral intake within the first 72 hours) of the cases with and without PHN were compared statistically in both patients over 65 and under 65 years of age.

\section{STATISTICAL ANALYSIS}

Statistical analysis was performed using IBM SPSS software version 22.0. The Shapiro-Wilk test was used to determine if the data were suitable for normal distribution. In the comparison of the two in- dependent groups, the independent sample t-test was used for the data that conformed to normal distribution, and these data were given with the mean \pm standard deviation. The Mann-Whitney $U$ test was used for the data that was not suitable for normal distribution, and these data were given with median (minimum-maximum) values. The Wilcoxon test was used to compare the two dependent groups. Pearson's chi-square test and the Fisher-Freeman-Halton test were used to compare categorical variables, and these data were given with frequency (percent) values. The significance level was accepted as $p=0.05$.

\section{RESULTS}

The mean age of the $90 \mathrm{HZ}$ cases was $58.8 \pm 16.1$ years old. There were 48 (53.3\%) females and 42 $(46.7 \%)$ males. While the number of antiviral intake within the first 72 hours was 41 (45.6\%), the number of those who did not take was not 49 (54.4\%). The mean initial median VAS score was $7.5(5 / 8)$, and it was $3.0(0 / 6)$ after 3 months. The affected dermatomes were as follows: thoracic 53 (58.9\%), lumbar 14 (15.6\%), cervical 12 (13.3\%), trigeminal 8 (8.9\%), and sacral 3 (3.3\%). (Table 1)

The variables affecting the VAS score in $90 \mathrm{HZ}$ cases after three months are as follows: 1) age was found significant $(p=0.004) ; 2)$ Gender was not found significant $(p=0.349) ; 3)$ antiviral intake within the first 72 hours was not found significant ( $p=0.835)$; 4) mean initial VAS score was found significant $(p<0.001) ; 5)$ affected dermatome was found significant ( $p=0.001)$; and 6 ) presence of chronic disease was found significant $(p=0.048)$. (Table 1)

PHN developed in 53 (58.9\%) of the 90 patients. In 53 cases with $\mathrm{PHN}$, there were 29 (54.7\%) cases over the age of 65 and $24(\% 45,2 \%)$ cases under the age of 65. (Table 2)

Initial and 3 months after median VAS scores were $8 / 4$ in cases over 65 years of age who devel- 
Table 1. Demographic and clinical data of 90 herpes zosterpatients. Variables that affecting the VAS score after 3 months in all patients.

\begin{tabular}{|c|c|c|c|}
\hline \multicolumn{2}{|c|}{ Variables } & HZ Patients $(n=90)$ & $\mathrm{p}$-volue \\
\hline \multicolumn{2}{|c|}{ Age* (year) } & $58.8 \pm 16.125$ & 0.004 \\
\hline $\begin{array}{l}\text { Initial } \\
\text { After three month }\end{array}$ & & $\begin{array}{l}7.5(5 / 8) \\
3.0(0 / 6) \\
\end{array}$ & $<0,001$ \\
\hline Gender\# & $\begin{array}{r}\text { Woman } \\
\text { Man } \\
\end{array}$ & $\begin{array}{l}48(53.3) \\
42(46.7) \\
\end{array}$ & 0.349 \\
\hline Antiviral treatmen & $\begin{array}{r}\text { Received } \\
\text { Not received } \\
\end{array}$ & $\begin{array}{l}41(45.6) \\
49(54.44) \\
\end{array}$ & 0.835 \\
\hline Affected dermator & $\begin{array}{r}\text { Servikal } \\
\text { Torakal } \\
\text { Lombal } \\
\text { Sakral } \\
\text { Trigeminal } \\
\end{array}$ & $\begin{array}{c}12(13.3) \\
53(58.9) \\
14(15.6) \\
3(3.3) \\
8(8.9) \\
\end{array}$ & 0.024 \\
\hline Chronic disease \# & $\begin{array}{l}\text { Yes } \\
\text { No }\end{array}$ & $\begin{array}{l}36(40.0) \\
54(60.0)\end{array}$ & 0.048 \\
\hline
\end{tabular}

Datasare given as¥ values, * mean \pm standard deviation, median (minimum / maximum) and\#n (\%)

oped PHN. Initial and 3 months after median VAS scores were $8 / 4$ in cases under 65 years of age who developed PHN. İnitial and 3 months after median VAS scores were $5 / 1$ in cases over 65 years of age who did not develop PHN. İitial and 3 months after median VAS scores were $5 / 1$ in cases under 65 years of age who did not develop PHN. (Table 2)

The number of women/men; over the age of 65 who developed PHN was 18/11, under the age of 65 who developed PHN was 11/13, over the age of 65 who did not develop PHN was 5/4, and under the age of 65 who did not develop PHN was 14/14. (Table 2)

Number of cases who had / had not antivirals within the first 72 hours; over the age of 65 who developed PHN was 11/18, under the age of 65 who developed PHN was 12/12, over the age of 65 who did not develop PHN was 4/5, and under the age of 65 who did not develop PHN was 14/14. (Table 2)
The number of patients with chronic disease, over the age of 65 who developed PHN was 18, under the age of 65 who developed PHN was 6, over the age of 65 who did not develop PHN was 5 , and under the age of 65 who did not develop PHN was 7. (Table 2)

The number of dermatomes affected in those over 65 years of age with PHN were thoracic 14, cervical 6, trigeminal 4, sacral 3, and lumbar 2 . The number of dermatomes affected in those under 65 years of age with PHN were thoracic 14, trigeminal 4, cervical 3, lumbar 3. The number of dermatomes affected in those over 65 years of age without PHN were thoracic 8 , lumbar 1 . The number of dermatomes affected in those under 65 years of age without PHN were thoracic 17, lumbar 8, cervical 3. (Table 2)

In-group comparison of variables affecting VAS scores after 3 months in $\mathrm{HZ}$ cases with PHN were as follows: 1) initial median VAS score was foundsig- 
Table 2. Demographic and clinical data of 90 herpes zoster cases divided into 4 groups according to age and development of postherpetic neuralgia.

\begin{tabular}{|c|c|c|c|c|}
\hline Variables & $\begin{array}{c}\text { Over the age of } 65 \text { who } \\
\text { developed PHN } \\
(n=29)\end{array}$ & $\begin{array}{l}\text { Over the age of } 65 \text { who } \\
\text { did not develop PHN } \\
(n=9)\end{array}$ & $\begin{array}{c}\text { Under the age of } 65 \text { who } \\
\text { developed PHN } \\
(n=24)\end{array}$ & $\begin{array}{l}\text { Under the age of } 65 \text { who } \\
\text { did not develop PHN } \\
(n=28)\end{array}$ \\
\hline $\begin{array}{l}\text { Initial } \\
\text { After } 3 \text { months }\end{array}$ & $\begin{array}{l}8(8-8) \\
4(4-5)\end{array}$ & $\begin{array}{l}5(5-6) \\
1(0-2)\end{array}$ & $\begin{array}{l}(8-8) \\
(4-5)\end{array}$ & $\begin{array}{c}(3.5-6.5) \\
(0-2)\end{array}$ \\
\hline $\begin{array}{l}\text { Woman } \\
\text { Man }\end{array}$ & $\begin{array}{l}18(62.0) \\
11(38.0)\end{array}$ & $\begin{array}{l}5(56.0) \\
4(44.0)\end{array}$ & $\begin{array}{l}11(46.0) \\
13(54.0)\end{array}$ & $\begin{array}{l}14(50.0) \\
14(50.0)\end{array}$ \\
\hline $\begin{array}{l}\quad \text { Antiviral treatment } \\
\text { Received } \\
\text { Not received }\end{array}$ & $\begin{array}{l}11(38.0) \\
18(62.0)\end{array}$ & $\begin{array}{l}4(44.0) \\
5(56.0)\end{array}$ & $\begin{array}{l}12(50.0) \\
12(50.0)\end{array}$ & $\begin{array}{l}14(50.0) \\
14(50.0)\end{array}$ \\
\hline $\begin{array}{l}\quad \text { Affected dermatomes }{ }^{\#} \\
\text { Torakal } \\
\text { Servikal } \\
\text { Lombal } \\
\text { Trigeminal } \\
\text { Sakral }\end{array}$ & $\begin{array}{l}14(48.0) \\
6(21.0) \\
2(7.0) \\
4(14.0) \\
3(10.0)\end{array}$ & $\begin{array}{c}8(89.0) \\
0(0) \\
1(11.0) \\
0(0) \\
0(0)\end{array}$ & $\begin{array}{c}14(58.3) \\
3(12.5) \\
3(12.5) \\
4(16.7) \\
0(0)\end{array}$ & $\begin{array}{l}17(60.7) \\
3(10.7) \\
8(28.6) \\
0(0) \\
0(0)\end{array}$ \\
\hline $\begin{array}{l}\text { Chronic disease \# } \\
\text { Yes } \\
\text { No }\end{array}$ & $\begin{array}{l}18(62.0) \\
11(38.0)\end{array}$ & $\begin{array}{l}5(56.0) \\
4(44.0)\end{array}$ & $\begin{array}{c}6(25.0) \\
18(75.0)\end{array}$ & $\begin{array}{c}7(25.0) \\
21(75.0)\end{array}$ \\
\hline
\end{tabular}

Datasare given as¥ values, * mean \pm standard deviation, median (minimum / maximum) and\#n (\%)

nificant in both cases over 65 and under 65 years of age ( $p<0.001)$, $p<0.001)$; 2 ) gender was not found significant over 65 years of age, but, under 65 years of age, it was found borderline significant $(p=0.349$, $(p=0.055) ; 3)$ over 65 years of age, the presence of chronic disease was found borderline significant $(p=0.058)$, but , under 65 years of age, it was found highly significant ( $p=0.001)$; 4 ) over 65 years of age, affected dermatome was found significant $(p=0.024)$, but, under 65 years of age, it was not found significant ( $p=0.365)$; and 5) antiviral intake within the first 72 hours was not found significant in both cases over 65 and under 65 years of age $(p=0.208, p=0.319)$. (Table 3-4)

\section{DISCUSSION}

$\mathrm{HZ}$ damages the nervous system. Although the specific mechanism that causes chronic pain has not been fully explained, it is believed that several pathophysiological mechanisms may contribute. One hypothesis is that in the acute phase, tissue damage and inflammation create nociceptive pain, and peripheral nerve damage creates neuropathic pain. Then, a progression from peripheral to central nervous system changes results in PHN. (11) Neuropathic pain is thought to be more closely related to progression to PHN. (12) There is increased neuronal excitability and alteration of pain perception caused by neural damage during $\mathrm{HZ}$ infection. (13)

The relative risk for development of $\mathrm{PHN}$ per 10year increase ranges from 1.22 to 3.11 , and $12.5 \%$ of patients with $\mathrm{HZ}$ are above 50 years of age. (14) Aging causes a decrease in cellular immunity, which makes it easier for the virus to reactivate and potentially lead to PHN. The presence of subclinical polyneuropathy in the elderly can cause PHN, even with mild viral damage. (15) In the current study, 
Table 3. Comparison of variables affecting the VAS score after 3months in cases with postherpetic neural gia.

\begin{tabular}{|c|c|c|c|c|}
\hline Variables & $\begin{array}{l}\text { Over the age of } 65 \\
\text { who developed PHN } \\
(n=29)\end{array}$ & $p$-value & $\begin{array}{c}\text { Under the age of } 65 \\
\text { who developed PHN } \\
(n=24)\end{array}$ & p-value \\
\hline VAS $*$ & 8 & $<0,001$ & 8 & $<0,001$ \\
\hline $\begin{array}{l}\text { Woman Gender \# } \\
\text { Man }\end{array}$ & $\begin{array}{l}18(62.0) \\
11(38.0)\end{array}$ & 0.349 & $\begin{array}{l}11(46.0) \\
13(54.0)\end{array}$ & 0.055 \\
\hline $\begin{array}{l}\text { Antiviral treatment } \\
\text { Received } \\
\text { Not received }\end{array}$ & $\begin{array}{l}11(38.0) \\
18(62.0)\end{array}$ & 0.208 & $\begin{array}{l}12(50.0) \\
12(50.0)\end{array}$ & 0.319 \\
\hline $\begin{array}{l}\quad \text { Affected dermatomes }{ }^{\#} \\
\text { Servikal } \\
\text { Torakal } \\
\text { Lombal } \\
\text { Sakral } \\
\text { Trigeminal }\end{array}$ & $\begin{array}{l}6(21.0) \\
14(48.0) \\
2(7.0) \\
4(14.0) \\
3(10.0)\end{array}$ & 0.024 & $\begin{array}{c}3(12.5) \\
14(58.3) \\
3(12.5) \\
4(16.7) 0(0)\end{array}$ & 0.365 \\
\hline $\begin{array}{l}\text { Chronic disease \# } \\
\text { Yes } \\
\text { No }\end{array}$ & $\begin{array}{l}18(62.0) \\
11(38.0)\end{array}$ & 0.058 & $\begin{array}{c}6(25.0) \\
21(75.0)\end{array}$ & 0.001 \\
\hline
\end{tabular}

Datasare given as¥ values, * mean \pm standard deviation, median (minimum / maximum) and\#n (\%)

Table 4. Summary of variables affecting the VAS score after 3 months in postherpetic neuralgia cases by p-value.

\begin{tabular}{|c|c|c|c|}
\hline & $\begin{array}{c}\text { Over the age of } 65 \text { andunder the age } \\
\text { ofwho developed PHN }\end{array}$ & $\begin{array}{l}\text { Over the age of } 65 \\
\text { who developed PHN }\end{array}$ & $\begin{array}{l}\text { Under the age of } 65 \\
\text { who developed PHN }\end{array}$ \\
\hline$p>0,05$ & $\begin{array}{l}{ }^{*} \text { Gender } \\
{ }^{*} \text { Antiviral treatment }\end{array}$ & $\begin{array}{l}{ }^{*} \text { Gender } \\
{ }^{*} \text { Antiviral treatment }\end{array}$ & $\begin{array}{l}\text { *Antiviral treatment } \\
{ }^{\star} \text { Affected dermatome }\end{array}$ \\
\hline$p=0,05-0,001$ & $\begin{array}{c}{ }^{\star} \text { Age } \\
\text { *Presence of chronic disease } \\
{ }^{\star} \text { Affected dermatome }\end{array}$ & $\begin{array}{l}\text { *Affected dermatome } \\
{ }^{*} \text { Presence of chronic disease }\end{array}$ & $\begin{array}{l}{ }^{*} \text { Gender } \\
* \text { Presence of chronic disease }\end{array}$ \\
\hline$p<0,001$ & *Initial VAS score & *Initial VAS score & *initial VAS score \\
\hline
\end{tabular}

while most of the $\mathrm{HZ}$ cases were under the age of 65 years, most of those who developed PHN were over 65 years old. Also in the current study, a strong relationship was found between age and development of PHN. Among the risk factors for PHN advanced age is associated with vaccination. These results suggest that vaccination may be important in preventing $\mathrm{PHN}$ in $\mathrm{HZ}$ cases over 65 years of age.

Many studies have found different results regarding the effect of gender on PHN development.
In most cases, female gender has been reported as a risk factor for the development of PHN. (16) This can be attributed to longer life expectancy among women and the greater likelihood of reporting pain. In the current study, male gender was found borderline significant in $\mathrm{HZ}$ cases under 65 years of age but not found significant in $\mathrm{HZ}$ cases over 65 years of age. These conflicting results may be due to heterogeneity between the studies.

Antiviral agents can inhibit the replication of 
VZV in the acute phase and prevent nerve damage. While some studies support the view that antiviral agents decrease the incidence of PHN, others do not agree and only report that PHN severity and duration may be decreased. In a review of $1211 \mathrm{HZ}$ patients, acyclovir was reported to be not superior to placebo in reducing the risk of PHN, so it was recommended that further studies should be conducted with other antivirals. (17) In the current study, antiviral (valacyclovir $1000 \mathrm{mg}$ three times daily for seven days) intake within the first 72 hours was not found significant for the development of PHN in $\mathrm{HZ}$ cases over and under 65 years of age. It is important to emphasize that antiviral therapy does not completely prevent PHN. However, in this study, it was observed that $39.4 \%$ of $\mathrm{HZ}$ cases over 65 years old and $50.0 \%$ of patients under 65 years old received antiviral therapy within the first 72 hours. According to this result, it can be thought that receiving antiviral treatment in the first 72 hours in $\mathrm{HZ}$ cases over 65 years old is worse than in $\mathrm{HZ}$ cases under 65 years of age. Many reasons such as disregard $\mathrm{HZ}$ rashes and not using the recommended antiviral treatment may prevent the intake of antiviral treatment in the first 72 hours. It may be important to increase the awareness of new rashes and to control drug intake for $\mathrm{HZ}$ cases over the age of 65 years.

In this study, as in many others, pain severity was found a significant risk factor for $\mathrm{PHN}$ in $\mathrm{HZ}$ cases. In the acute phase of $\mathrm{HZ}$, suppression of nerve stimulation at an early stage may reduce the development of PHN. Therefore, many studies have investigated the effect of pain therapy on the development of $\mathrm{PHN}$ with $\mathrm{HZ}$ patients. Antiepileptics, tricyclic antidepressants, and opioids might have an effect on the molecular changes that occur in peripheral nerves and in the central nervous system. (18) It has been reported that steroids and antidepressants were not preventative. (19) Also, the role of nonpharmacological treatments is unclear. (20) Electroacupuncture (21) and transcutaneous electrical nerve stimulation (22) were effective in resolving the rash, decreasing herpes-related pain, and even preventing PHN. Interventional procedures, such as sympathetic nerve blocks and intrathecal and epidural analgesia, aimed at inhibiting painful stimuli transmission and reducing inflammation in this area may prevent PHN. (23)

Various immunocompromised patient populations (patients with neoplastic diseases, organ transplant recipients, and those receiving immunosuppressive drugs), HIV-positive patients, and patients with diabetes have been shown to be at increased risk for $\mathrm{HZ}$ and PHN. $(24,25)$ Concomitant diseases, multiple drug use, and decreased physiological reserve may make it difficult for some elderly patients to eliminate $\mathrm{HZ}$ without complications. Similarly, in this study, the presence of chronic disease was found an important risk factor for the development of $\mathrm{PHN}$ in both $\mathrm{HZ}$ cases over and under 65 years of age. However, this relationship between the presence of chronic disease and the development of PHN was more evident in $\mathrm{HZ}$ cases under 65 years of age.

Findings regarding the location of the rashes in this study were similar to those in many studies. $\mathrm{HZ}$ rashes were unilateral, did not cross the midline, and the most commonly affected dermatome was thoracic, followed by cervical, trigeminal, lumbar, and sacral dermatomes. A meta-analysis of 19 prospective studies showed significant increases in the risk of PHN with the ophthalmic division of trigeminal nerve involvement. (26) In the current study, while trigeminal and sacral dermatome involvement was found a risk factor for the development of $\mathrm{PHN}$ in $\mathrm{HZ}$ cases over 65 years old. But affected dermatome was not found a risk factor for the development of $\mathrm{PHN}$ in $\mathrm{HZ}$ cases under 65 years old. However, the reason for this may be that trigeminal and sacral dermatome involvement in the $\mathrm{HZ}$ cases over 65 years old was approximately two times more than in the $\mathrm{HZ}$ cases under 65 years old.

In conclusion, advanced age and presence of chronic disease is an important risk factors in the 
development of PHN with $\mathrm{HZ}$ cases.PHN cannot be prevented completely with any treatment other than vaccination. Vaccination may be important in preventing $\mathrm{PHN}$ in $\mathrm{HZ}$ cases over 65 years of age especially with presence of chronic disease. However, earlier and advanced treatments that reduce central sensitization may be considered in the acute stage of $\mathrm{HZ}$ cases with severe initial pain. Risk factors for

\section{REFERENCES}

1. Al-Turab M, Chehadeh W. Varicella infection in the Middle East: Prevalence, complications, and vaccination. J Res Med Sci. 2018 Apr 26;23:19. (PMID: 29887897)

2. Watanabe D. [Cutaneous Herpesvirus Infection]. Brain Nerve. 2019 Apr;71(4):302-308. ( PMID: 30988211)

3. Chapman RS, Cross KW, Fleming DM. The incidence of shingles and its implications for vaccination policy. Vaccine 2003; 21(19-20):2541-7.(PMID: 12744889)

4. Friesen KJ, Chateau D, Falk J, Alessi-Severini S, Bugden S. Cost of shingles: population based burden of disease analysis of herpes zoster and postherpetic neuralgia. BMC Infect Dis. 2017 Jan 13;17(1):69. (PMID: 28086817)

5. Weaver BA. The burden of herpes zoster and postherpetic neuralgia in the United States.J AmOsteopathAssoc2007;107(3 ):2-7. (PMID: 17488884 )

6. Johnson RW, Bouhassira D,Kassianos G, Leplege A, Schmader KE, Weinke T. The impact of herpes zoster and post-herpetic neuralgia on quality-of-life. BMC Med 2010; 8:37. (PMID: 20565946 )

7. Inata K, Miyazaki D, Uotani R et.al. Effectiveness of real-time PCR for diagnosis and prognosis of varicella-zoster virus keratitis. Jpn J Ophthalmol. 2018 Jul;62(4):425-431. (PMID: 29948430)

8. Gross GE, Eisert L, Doerr HW et al. S2k guidelines for the diagnosis and treatment of herpes zoster and postherpetic neuralgia. J Dtsch Dermatol Ges 2020;18(1):55-78. (PMID: 31951098 )

9. Reid MC, Pillemer K.Management of chronic pain in older adults. BMJ 2015; 350:532. (PMID: 25680884 )

10. Zhou J, Li J, Ma L, Cao S. Zoster sine herpete: a re- the development of PHN in geriatric $\mathrm{HZ}$ cases indicate some differences compared to young and middle-aged $\mathrm{HZ}$ cases. Therefore, special protection, follow-up and treatment is needed to prevent the development of PHN in $\mathrm{HZ}$ cases over 65 years of age, especially those with sacral and trigeminal dermatomes and presence of chronic disease.

view. Korean J Pain. 2020 Jul 1;33(3):208-215. ( PMID: 32606265)

11. Dworkin RH, Perkins FM, Nagasako EM: Prospects for the prevention of postherpetic neuralgia in herpes zoster patients. Clin J Pain 2000;16: 90-100. (PMID: 10870747 )

12. Jung BF, Johnson RW, Griffin DR, Dworkin RH: Risk factors for postherpetic neuralgia in patients with herpes zoster. Neurology 2004; 62(9):1545-1551. (PMID: 15136679)

13. Harpaz R, Nagel MA, Schmader K, Tyring SK, Yawn BP. Roundtable on postherpetic neuralgiawhat, why, how long, and what's next? Popul Health Manag2012;15(6):385-90. (PMID: 23088665)

14. Forbes HJ, Thomas SL, Smeeth L et al. A systematic review and meta-analysis of risk factors for postherpetic neuralgia . Pain 2016; 157(1):30-54. (PMID: 26218719)

15. Baron R, Haendler G, Schulte H. Afferent large fiber polyneuropathy predicts development of postherpetic neuralgia. Pain 1997;73(2):231-8.(PMID: 9415510)

16. Coen PG, Scott F, Leedham-Green $M$ et al.Predicting and preventing post-herpetic neuralgia: are current risk factors useful in clinical practice? Eur J Pain 2006; 10(8):695-700. (PMID: 16427792)

17. Chen N, Li Q, Yang J, Zhou M, He L. Antiviral treatment for preventing postherpetic neuralgia. Cochrane Database of Systematic Reviews 2014; (2):CD006866. (PMID: 24500927)

18. Bennett GJ. Hypotheses on the pathogenesis of herpes zoster associated pain. Ann Neurol 1994; 35 Suppl:S38-41. (PMID: 8185295)

19. Saarto T, Wiffen PJ. Antidepressants for neuropathic pain: a Cochrane review. J Neurol Neurosurg Psychiatry 2010; 81(12):1372-3. (PMID: 20543189) 
20. Opstelten W, Wijck AJ, Stolker RJ. Interventions to prevent postherpetic neuralgia: cutaneous and percutaneous techniques. Pain. 2004; 107(3):202-6. (PMID: 14736581)

21. Wu CH, Lv ZT, Zhao Y, et al. Electroacupuncture improves thermal and mechanical sensitivities in a rat model of postherpetic neuralgia. Pain 2013; 9:18. (PMID: 23551937 )

22. Kolsek M. TENS an alternative to antiviral drugs for acute herpes zoster treatment and postherpetic neuralgia prevention. Swiss Med Wkly 2012;141:w13229. (PMID: 22250036)

23. Kumar V, Krone K, Mathieu A. Neuraxial and sympathetic blocks in herpes zoster and postherpetic neuralgia: An appraisal of current evidence. Reg Anesth
Pain Med2004; 29(5):454-61. (PMID: 15372391)

24. Gebo KA, Kalyani R, Moore RD, Polydefkis MJ. The incidence of, risk factors for, and sequelae of herpes zoster among HIV patients in the highly active antiretroviral therapy era. J Acquir Immune Defic Syndr 2005 ;40(2):169-74. (PMID: 16186734 )

25. Jih JS, Chen YJ, Lin MW et al. Epidemiological features and costs of herpes zoster in Taiwan: a national study 2000 to 2006. Acta Derm Venereol 2009;89(6):612-6. (PMID: 19997693)

26. Oxman MN, Levin MJ, Johnson GR, et al. A vaccine to prevent herpes zoster and postherpetic neuralgia in older adults. N Engl J Med 2005 ; 352(22):2271-84. (PMID: 15930418) 